\title{
Tumor Necrosis Factor-Alpha Up-Regulates ICAM-1 Expression and Release in Intestinal Myofibroblasts by Redox-Dependent and -Independent Mechanisms
}

\author{
Filippo Fontani, ${ }^{1}$ Vladana Domazetovic, ${ }^{1}$ Tommaso Marcucci, ${ }^{2}$ Maria Teresa Vincenzini, ${ }^{1}$ \\ and Teresa Iantomasi ${ }^{1 *}$ \\ ${ }^{1}$ Department of Biomedical, Experimental and Clinical Sciences "Mario Serio", University of Florence, \\ Viale Morgagni 50, 50134 Florence, Italy \\ ${ }^{2}$ Santa Maria Annunziata Hospital, Section of General Surgery, 50126 Via dell'Antella 58, \\ Ponte a Niccheri (Florence), Italy
}

\begin{abstract}
Intercellular adhesion molecule-1 (ICAM-1) is distributed and expressed on cell surface and is present in circulation as soluble form (sICAM-1). Tumor necrosis factor-alpha (TNF $\alpha$ ) and radical oxygen species (ROS) up-regulate the expression of ICAM-1. This study demonstrates for the first time in 18 Co cells, a myofibroblast cell line derived from human colonic mucosa, an up-regulation of ICAM-1 expression and sICAM-1 release induced by oxidative stress and TNF $\alpha$ stimulation. The intracellular redox state was modulated by L-buthionine-S,R-sulfoximine (BSO) or $\mathrm{N}$-acetylcysteine (NAC), inhibitor and precursor respectively of GSH synthesis. ROS production increases in cells treated with BSO or TNF $\alpha$, and this has been related to an up-regulation of ICAM-1 expression and sICAM-1 release. The involvement of metalloproteinases in ICAM-1 release has been demonstrated. Moreover, also expression and activation of A disintegrin and metalloproteinase 17, a membrane-bound enzyme known as TNF $\alpha$-converting enzyme (TACE), have been related to ROS levels. This suggests the possible involvement of TACE in the cleavage of ICAM-1 on cell surface in condition of oxidative stress. NAC down-regulates the expression and release of ICAM-1 as well as the expression and activation of TACE. However, in TNF $\alpha$ stimulated cells NAC treatment reduces only in part ICAM-1 expression and sICAM-1 release. Given this TNF $\alpha$ may also act on these events by a redox-independent mechanism. J. Cell. Biochem. 117: 370-381, $2016 . \quad$ ○) 2015 Wiley Periodicals, Inc.
\end{abstract}

KEY WORDS: $\mathrm{H}_{2} \mathrm{O}_{2}$ PRODUCTION; OXIDATIVE STRESS; ICAM-1 SOLUBLE FORM; REDOX REGULATION; TACE

$\mathrm{I}$ ntercellular adhesion molecule-1 (ICAM-1) is a glycoprotein extensively distributed and expressed on cell surface of various cell types such as fibroblasts, endothelial and epithelial cells, and leukocytes [Hua, 2013]. The role of ICAM-1 is crucial in immune response inducing the trans-migration of leukocytes to inflammatory sites. ICAM-1 also mediates the intracellular signal transduction pathway, through outside-in signalling event, and the cell-matrix adhesion. Moreover, it promotes the adhesion of cancer cells and is involved in the immune response of tumors [Lawson and Wolf, 2009; Arteta et al., 2010; Ksiazek et al., 2010]. In addition, ICAM-1 is present in circulation as soluble form (sICAM-1), lacking the transmembrane and cytoplasmic domains. sICAM-1 results from proteolytic cleavage of cell surface ICAM-1 through a process that does not depend on the amount of ICAM-1 present on membranes [Lawson and Wolf, 2009; Hua, 2013]. In particular, proteases involved in ICAM-1 cleavage are matrix metalloproteinases (MMPs) [Lawson and Wolf, 2009], A disintegrin and metalloproteinase 17, a membrane-bound enzyme known as tumor necrosis factor-alpha $(\mathrm{TNF} \alpha)$-converting enzyme (TACE), [Tsakadze et al., 2006] and elastase, a serine proteinase secreted by neutrophils and macrophages during inflammation [Champagne et al., 1998]. Although sICAM-1 can have a good therapeutic effect by blocking cell-cell adhesion, it plays a role in chronic inflammatory processes by stimulating the cytokine production [McCabe et al., 1993; Otto et al., 2000], the activation of mitogen activated protein kinases (MAPK) [Otto et al., 2002] and transcriptional factors [Schmal et al., 1998].

An up-regulation and/or over-expression of ICAM-1 and sICAM1 have been found in tumors, such as melanoma, pancreatic cancer and colorectal cancer (CRC), suggesting a role of ICAM-1 in the malignant progression [Maeda et al., 2002; Roland et al., 2007,2010].

Conflicts of interest: The authors have not conflict of interest.

Grant sponsor: Fondazione Cassa di Risparmio di Firenze; Grant number: 2011.0300.

*Correspondence to: Teresa Iantomasi, Department of Biomedical, Experimental and Clinical Sciences "Mario Serio"

Viale Morgagni 50, 50134 Firenze. E-mail: tiantomasi@unifi.it

Manuscript Received: 14 April 2015; Manuscript Accepted: 8 July 2015

Accepted manuscript online in Wiley Online Library (wileyonlinelibrary.com): 14 July 2015

DOI 10.1002/jcb.25279 • (c) 2015 Wiley Periodicals, Inc. 
In particular, an increase of ICAM-1 on the surface of neoplastic cells mediates the attachment of these cells to the extracellular matrix, with the consequent decrease of metastases and increase of tumor differentiation [Taglia et al., 2007]. On the contrary, sICAM-1 is involved in tumor invasion and in development of metastasis in various cancer types [Nakata et al., 2000; Perabo et al., 2001; Maeda et al., 2002; 0'Hanlon et al., 2002].

Pro-inflammatory mediators, cytokines, and radical oxygen species (ROS) up-regulate the expression of ICAM-1 [Roebuck and Finnegan, 1999; Ying et al., 2009; Angel-Morales et al., 2012; PinaCanseco Mdel et al., 2012]. In fact, an increased expression of ICAM1 occurs in different pathological inflammatory conditions, such as psoriasis, atherosclerosis, autoimmune diseases and inflammatory bowel diseases (IBD) [Chatterjee, 1998; Metselaar and Storm, 2005; Van Assche and Rutgeerts, 2005]. High levels of ICAM-1 expression have been found in IBD patients and during experimental colitis [Vainer et al., 2000; Chidlow et al., 2006]. In particular, in patients with Crohn's Disease (CD), an enhanced expression of ICAM-1 in the intestinal mucosa has been demonstrated [Ghosh and Panaccione, 2010]. In addition, high serum levels of sICAM-1, which probably derive from the cutting of ICAM-1 from cell surface within gut mucosa, have been measured in CD patients [Nielsen et al., 1994]. High levels of sICAM-1 are also present in serum of patients with CRC [Alexiou et al., 2001] that represents an elevated risk for IBD patients [Feagins et al., 2009; Grivennikov, 2013]. A risk factor for carcinogenesis in IBD patients is the enhanced oxidative state [0'Connor et al., 2010] present in the intestinal mucosa and intestinal subepithelial myofibroblasts (ISEMFs) of these patients [Iantomasi et al., 1994; Buffinton and Doe, 1995; Catarzi et al., 2011a].

ISEMFs, mesenchymal cells localized at interface between enterocytes and lamina propria, regulate various functions of normal and tumoral epithelial cells, stimulate colon tumorigenesis [Pinchuk et al., 2010] and are involved in the colorectal metastases [Yeung et al., 2013]. Moreover, ISEMFs express adhesion molecules, such as ICAM-1 [Pang et al., 1994]. In the literature, to our knowledge, no data are reported on the release of SICAM- 1 by these cells and the redox regulation of ICAM-1 and SICAM- 1 in ISEMFs.

In this study, we investigated the role of ROS on ICAM-1 expression and sICAM-1 release in myofibroblasts stimulated or not by $\mathrm{TNF} \alpha$. Indeed, TNF $\alpha$ is an important pro-inflammatory mediator related to the regulation of inflammatory signalling pathways in IBD [Biasi et al., 2013]. Moreover, a redox regulated mechanism of TACE expression and activation was also investigated. For this purpose, we performed experiments using a myofibroblast cell line derived from human colonic mucosa, CCD-18Co (18Co) cells which exhibit many properties of ISEMFs [Valentich et al., 1997]. In these cells, the intracellular redox state was modulated by L-buthionine-S, Rsulfoximine (BSO) or N-acetylcysteine (NAC), inhibitor and precursor respectively of GSH synthesis [Catarzi et al., 2011a].

\section{MATERIALS AND METHODS}

\section{CELL CULTURE AND TREATMENT}

CCD-18Co (18Co) cells, obtained from American Type Culture Collection (Manassas, VA), were used in our experiments with PDL
27-36, given that the line begins to senescence at about PDL $=42$. The substances used for cell cultures and cell treatments were purchased from Sigma (St. Louis, MO). Cells were cultured at $37^{\circ} \mathrm{C}$ in a $5 \% \mathrm{CO}_{2}$ atmosphere in minimum essential medium with $2 \mathrm{mM}$ glutamine and $1.5 \mathrm{~g} / \mathrm{L}$ sodium bicarbonate, $0.1 \mathrm{mM}$ non-essential amino acids, $1 \mathrm{mM}$ sodium pyruvate and 10\% fetal bovine serum. Culture media were supplemented with $72 \mathrm{mg} / \mathrm{L}$ penicillin and $100 \mathrm{mg} / \mathrm{ml}$ streptomycin. Experiments were performed in 18Co cells serum starved at confluence for $24 \mathrm{~h}$ and treated or not during the last $16 \mathrm{~h}$ with $25 \mu \mathrm{M}$ BSO or $20 \mathrm{mM}$ NAC or NAC+BSO. Subsequently, the cells were stimulated or not for other $24 \mathrm{~h}$ with various concentrations of $\mathrm{TNF} \alpha(1-30 \mathrm{ng} / \mathrm{ml})$. Additional experiments were performed in $24 \mathrm{~h}$ serum starved $18 \mathrm{Co}$ cells treated or not, during the last $16 \mathrm{~h}$, with BSO in the presence or absence of $10 \mu \mathrm{M}$ TNF $\alpha$-protease inhibitor-1 (TAPI-1) or $10 \mu \mathrm{M}$ diphenyleneiodonium (DPI). In experiments with DPI, we added 0.003\% DMSO (vehicle for DPI) in the respective DPI untreated cells. Subsequently these cells were stimulated for $24 \mathrm{~h}$ with TNF $\alpha$. The concentrations of all compounds used did not reduce the viability according to Trypan blue exclusion test.

\section{INTRACELLULAR ROS PRODUCTION ASSAY}

The intracellular production of ROS was assayed, as previously described [Catarzi et al., 2011b], in 18Co cells seeded in 12-well plates, serum starved and treated as above described. Thirty minutes before the end of the various treatments, $5 \mathrm{~g} / \mathrm{L} 2^{\prime}-7^{\prime}$-dichlorodihydrofluorescein diacetate $\left(\mathrm{H}_{2}\right.$ DCFDA) was added in culture medium. After PBS washing, adherent 18Co cells were lysed in $50 \mathrm{mM}$ Tris/HCl pH 7.5, 1\% Triton X100, 150 mM NaCl, 100 mM NaF, 2mM EGTA (RIPA buffer) and analysed immediately by fluorescence spectrophotometric analysis at $510 \mathrm{~nm}$. Data have been normalized on total protein content and values were expressed as percent of ROS production measured in untreated and unstimulated cells (control).

\section{ICAM-1 AND sICAM-1 ASSAY}

sICAM-1 release and intracellular ICAM-1 levels were measured in cell lysate and in the respective culture medium, using Human ICAM-1 ELISA kit (Uscn Life Sciences Inc., Wuhan, Hubei, PRC) in accordance whit the manufacturer's instructions. 18Co cells were seeded in 12-well plates and treated as above described. For the cell lysates preparation, cells were detached with trypsin and collected by centrifugation at $130 \mathrm{~g}$ for $10 \mathrm{~min}$. Cells, washed three times in cold phosphate buffer saline (PBS), were resuspended in PBS and ultrasonicated for 4 times. Subsequently, the cell lysates were centrifugated at $1,500 \mathrm{~g}$ for $10 \mathrm{~min}$ to remove cellular debris and ICAM-1 assay was performed in the supernatants. Data have been normalized on total protein content and sICAM-1 and ICAM-1 levels were expressed as percent of the respective levels measured in control.

\section{WESTERN BLOTTING}

ICAM-1 and TACE expression analysis was performed by Western blot in 18Co cells seeded in p-60 plates treated and stimulated or not as above described. Cells were lysed in ice cold RIPA buffer containing phosphatase and protease inhibitor cocktails, 
purchased from Sigma and, after 15 min on ice, were centrifuged at $11,600 \mathrm{~g}$ for $10 \mathrm{~min}$. Immunochemical detection of ICAM-1 was performed also in the membrane fraction purified as previously reported [Catarzi et al., 2005]. Protein concentrations were determined by the bicinchoninic acid solution (BCA) protein reagent assay (Pierce) [Smith et al., 1985] using bovine serum albumin as standard (Sigma). Equal amount of total proteins (30-35 $\mu \mathrm{g}$ ) were loaded in each line and were subjected to sodium dodecyl sulphate-polyacrylamide gel electrophoresis (SDS/PAGE) on $10 \%(\mathrm{w} / \mathrm{v})$ gel and electrotransferred to PVDF membrane (GE Healtcare) that was probed with specific antibodies anti-ICAM-1 or anti- $\beta$-actin (Santa Cruz Biotechnology, INC.). For the detection of TACE and TACE phosphorylated at Thr735, the samples were lyophilized and $100 \mu \mathrm{g}$ of proteins were subjected to SDS/PAGE on 10\% (w/v) gel. PVDF membranes were probed with anti-TACE (Santa Cruz Biotechnology, INC.) or anti- $\beta$-actin. Subsequently, the membranes were stripped by incubation for $30 \mathrm{~min}$ at $50^{\circ} \mathrm{C}$ in buffer containing $62.5 \mathrm{mM}$ Tris $/ \mathrm{HCl}, \mathrm{pH} 6.7,100$ nM 2-mercaptoethanol, 2\% SDS and, after extensive washing, the membranes were reprobed with anti-ADAM17-phospho-Thr735 (MyBioSource). $\beta$-actin bands were used to normalize and to perform a densitometric analysis. Secondary antibodies conjugated to horseradish peroxidase were used to detect antigenantibody complexes with a chemiluminescence reagent kit (GE Healtcare). Chemidoc-Quantity-One software (Biorad Laboratories) was used to perform quantitative analyses and band values were expressed as percentage variations relative to controls.

\section{STATISTICAL ANALYSIS}

All experiments were carried out four or more times. Data are expressed as the mean \pm SEM and statistical significance of the differences was determined using Student's $t$ test. $P \leq 0.05$ was considered statistically significant.

\section{EFFECT OF BSO, NAC, AND TNF $\alpha$ ON INTRACELLULAR ROS LEVELS IN 18 Co CELLS}

In Figure 1 the intracellular ROS production measured in 18Co cells in different experimental conditions is reported. The cells were treated or not with BSO or NAC or both and, subsequently, stimulated or not with $1 \mathrm{ng} / \mathrm{ml} \mathrm{TNF} \alpha(\mathrm{TNF} \alpha 1)$, physiological concentration [Corredor et al., 2003], and $10 \mathrm{ng} / \mathrm{ml} \mathrm{TNF} \alpha$ (TNF $\alpha$ 10), concentration at which the maximum effect has been observed. BSO and TNF $\alpha$ increased significantly ROS production in 18Co cells as compared to untreated and unstimulated cells (control) (Fig. 1). Interestingly, TNF $\alpha 1$ increased ROS levels similarly to that observed in BSO treated cells. Moreover, it enhanced significantly ROS production in BSO treated 18 Co cells, as compared to cells stimulated and treated separately with TNF $\alpha$ or BSO, reaching the value obtained with TNF $\alpha 10$ (Fig. 1). In fact, TNF $\alpha 10$ enhanced ROS intracellular levels, as compared to TNF $\alpha$ 1 stimulated 18Co cells, and BSO treatment did not make a further increase. Figure 1 shows that NAC treatment reduced significantly ROS levels, as compared to control cells, and this effect was also observed both in BSO treated cells and TNF $\alpha 1$ stimulated cells. On the contrary, NAC restored ROS levels to control values in all the other conditions (TNF $\alpha 10, \mathrm{BSO}+\mathrm{TNF} \alpha 1$, and $\mathrm{BSO}+\mathrm{TNF} \alpha 10)$.

\section{EFFECT OF BSO, NAC, AND TNF $\alpha$ ON ICAM-1 EXPRESSION AND sICAM-1 RELEASE IN 18Co CELLS}

Considering the effects of BSO, NAC, and TNF $\alpha$ on the changes of intracellular oxidative state, under the same experimental conditions, ICAM-1 expression and sICAM-1 release were detected by Western blot analysis of cell lysates and by ELISA kit in culture medium, respectively. Figure 2A shows that ICAM-1 increased both in BSO treated and TNF $\alpha$ stimulated cells, as compared to control. It is noteworthy that the enhancement of ICAM-1 expression was

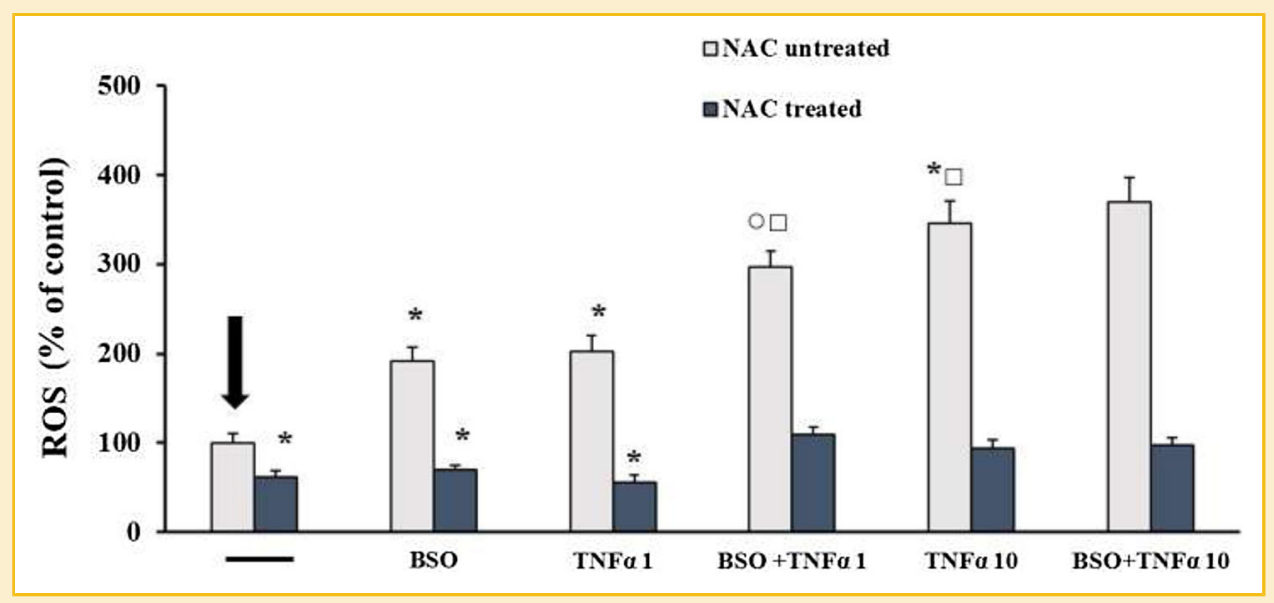

Fig. 1. Intracellular ROS production in 18 Co cells treated or not with BSO or NAC and stimulated with TNF $\alpha$. Starved 18 Co cells, treated or not with $25 \mu M$ BSO or 20 mM NAC as reported in Materials and Methods, were stimulated or not for $24 \mathrm{~h}$ with $1 \mathrm{ng} / \mathrm{ml}$ TNF $\boldsymbol{\alpha}$ (TNF $\alpha 1$ ) or $10 \mathrm{ng} / \mathrm{ml}$ TNF $\boldsymbol{\alpha}$ (TNF $\boldsymbol{\alpha} 10$ ). The intracellular ROS production was detected by measuring the fluorescence intensity of the intracellular oxidation-sensitive probe $\mathrm{H}_{2}$ DCFDA. The values, normalized on total protein content and expressed as percent of untreated and unstimulated cells (control, $100 \%$, indicated with the arrow), are the mean \pm SEM of six experiments repeated in triplicate. ${ }^{*} P \leq 0.05$ compared to the control cells; $\square P \leq 0.005$ compared to NAC untreated and TNF $\alpha 1$ stimulated cells; ${ }^{\circ} P \leq 0.001$ compared to NAC untreated and BSO treated cells. 


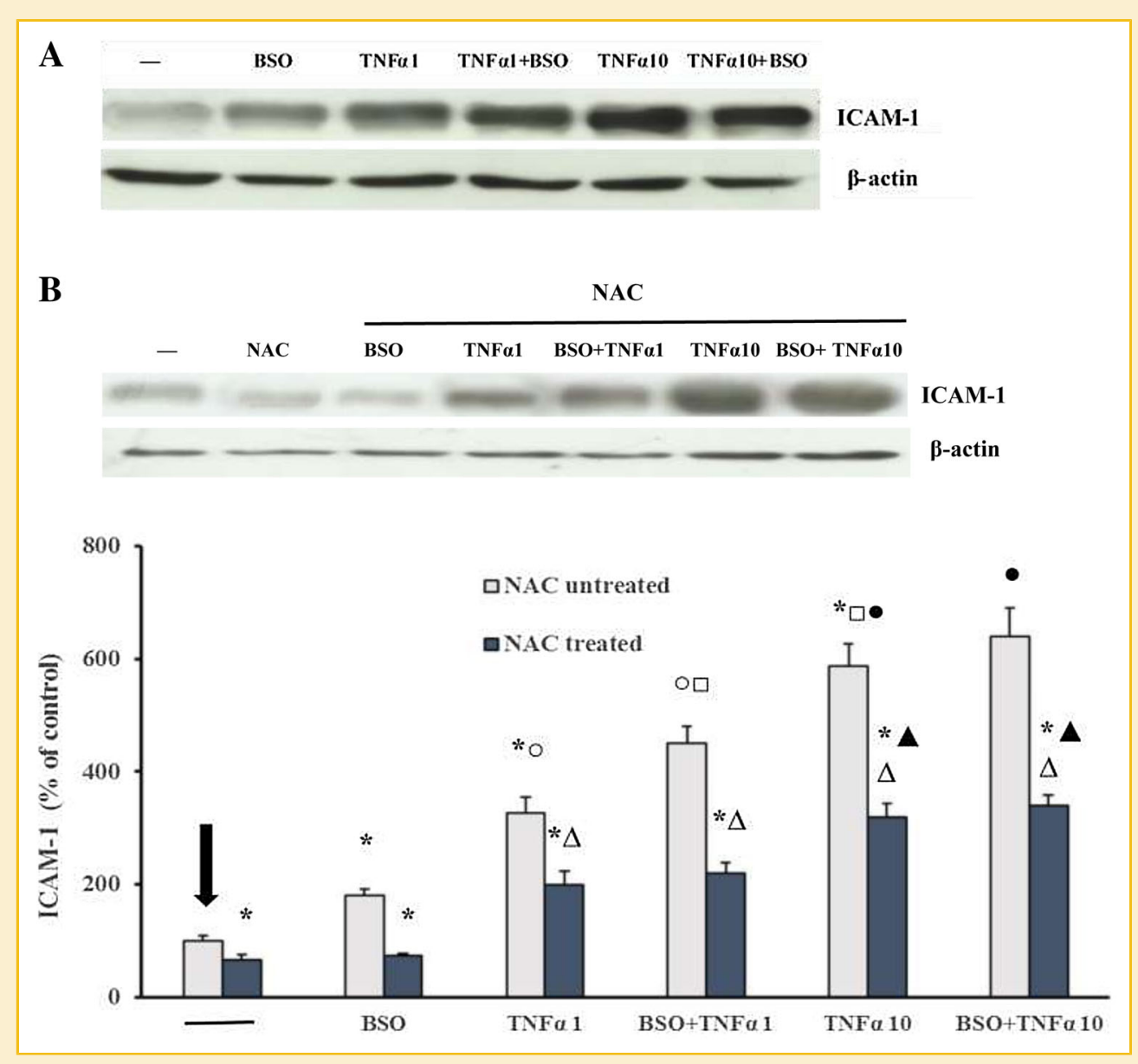

Fig. 2. ICAM-1 expression in 18 Co cells treated or not with BSO or NAC and stimulated with TNF $\alpha$. Starved $18 C$ ce cells, treated or not with $25 \mu M B S O$ (A) or or 20 mM NAC (B) as reported in Materials and Methods, were stimulated or not for $24 \mathrm{~h}$ with $1 \mathrm{ng} / \mathrm{ml}$ TNF $\alpha$ (TNF $\alpha 1$ ) or $10 \mathrm{ng} / \mathrm{ml}$ TNF $\alpha$ (TNF $\alpha 10)$. For the detection of ICAM-1 expression Western blot analysis of cell lysate with anti-ICAM- 1 and anti $\boldsymbol{\beta}$-actin was performed. Blot is representative of four experiments and the normalized values with actin bands obtained by densitometric analysis of four experiments are reported in the bottom. The values are the mean percentage \pm SEM relative to those obtained in the untreated and unstimulated cells (control, $100 \%$, indicated with the arrow). ${ }^{*} \boldsymbol{P} \leq 0.05$ compared to the control cells. $\square \boldsymbol{P} \leq 0.05$ compared to NAC untreated and TNF $\boldsymbol{\alpha} 1$ stimulated cells; ${ }^{\circ} \boldsymbol{P} \leq 0.05$ compared to NAC untreated and BSO treated cells; $\bullet P \leq 0.05$ compared to NAC untreated and BSO+TNF $\alpha 1$ treated cells; ${ }^{\Delta} P \leq 0.05$ compared to the respective NAC untreated cells; $\Delta P \leq 0.05$ compared to the respective NAC treated and TNF $\alpha 1$ stimulated cells.

maximum in TNF $\alpha 10$ stimulated cells and significantly higher than that measured in TNF $\alpha 1$ stimulated cells. Both TNF $\alpha$ concentrations increased significantly ICAM-1 expression as compared to BSO treated cells. ICAM-1 expression was up-regulated only in BSO + TNF $\alpha 1$ treated 18Co cells, as compared to TNF $\alpha 1$ stimulated cells, and the value obtained was significantly lower than that detected in 10 TNF $\alpha$ stimulated cells. No further increase of ICAM-1 expression was observed in BSO + TNF $\alpha$ 10, as compared to TNF $\alpha 10$ stimulated cells (Fig. 2A). Subsequently, we measured ICAM-1 expression in 18 Co cells treated with NAC. Figure $2 \mathrm{~B}$ shows that NAC treatment in all conditions down-regulated ICAM-1 expression, but this was reduced significantly only in NAC and NAC + BSO treated cells as compared to control. In NAC treated cells stimulated with both TNF $\alpha$ concentrations, the expression of ICAM-1 was higher than that of control cells but significantly lower than that measured in the respective TNF $\alpha$ stimulated cells. Moreover, NAC significantly decreased ICAM-1 expression in both TNF $\alpha 1$ and BSO + TNF $\alpha 1$ cells, as compared to the value measured under the same conditions in TNF $\alpha 10$ and BSO + TNF $\alpha 10$ stimulated 18Co cells (Fig. 2B). In all these experimental conditions Western blot was performed on purified membranes and the results were similar to those obtained in cell lysates (data not shown). Figure 3 shows that sICAM-1 release followed roughly the same trend of ICAM-1 expression. Differently to that occurred for ICAM-1 expression, a similar release of sICAM-1 was measured in BSO treated cells and in TNF $\alpha 1$ stimulated cells as compared to control value. Only TNF $\alpha 10$ was able to enhance sICAM-1 release with respect to BSO treated 18Co cells. Moreover, NAC treatment restored the values of SICAM-1 release to control level in BSO treated cells and in all TNF $\alpha 1$ stimulated cells but not in 18Co cells stimulated with TNF $\alpha$ 10. In fact, in NAC treated cells stimulated with TNF $\alpha 10$ the release of sICAM-1 was higher than that measured in control cells (Fig. 3). 


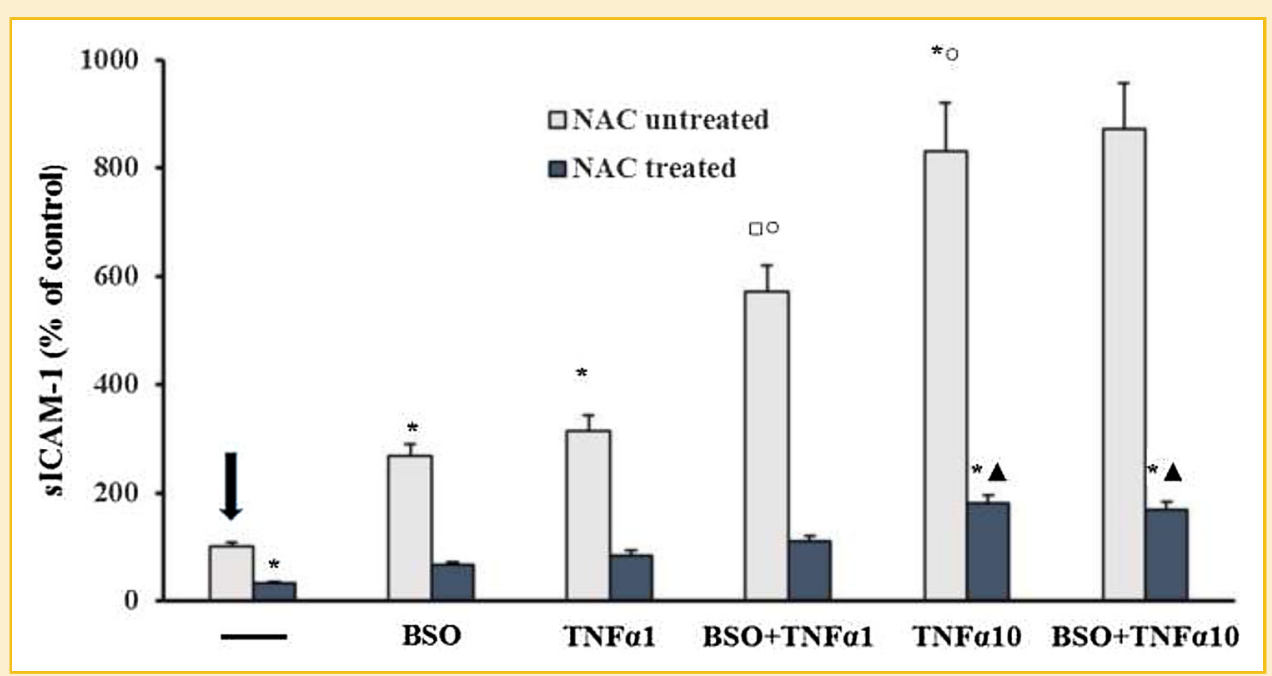

Fig. 3. sICAM-1 levels in 18 Co cells treated or not with BSO or NAC and stimulated with TNF $\alpha$. Starved cells, treated or not with $25 \mu M$ BSO or $20 \mathrm{mM}$ NAC as reported in Materials and Methods, were stimulated or not for $24 \mathrm{~h}$ with $1 \mathrm{ng} / \mathrm{ml} \mathrm{TNF} \boldsymbol{\alpha}$ (TNF $\alpha 1$ ) or $10 \mathrm{ng} / \mathrm{ml} \mathrm{TNF} \boldsymbol{\alpha}$ (TNF $\alpha 10)$. The culture medium was collected and used for sICAM- 1 assay by immunoenzymatic method. The values, expressed as percent of untreated and unstimulated cells (control, 100\%, indicated with the arrow), are the mean \pm SEM of six experiments repeated in triplicate. ${ }^{*} P \leq 0.05$ compared to the control cells. $\square \boldsymbol{P} \leq 0.05$ compared to NAC untreated and TNF $\alpha 1$ stimulated cells. ${ }^{\circ} \boldsymbol{P} \leq 0.05$ compared to NAC untreated and BSO treated cells; $\mathbf{\Delta} \leq 0.05$ compared to the respective NAC treated and TNF $\boldsymbol{\alpha} 1$ stimulated cells.

\section{INVOLVEMENT OF MMPS AND NADPH OXIDASE ON SICAM-1 RELEASE AND INTRACELLULAR ICAM-1 LEVELS IN 18Co CELLS TREATED WITH BSO AND STIMULATED WITH TNF $\alpha$}

The involvement of redox regulated MMPs on sICAM-1 release in 18Co cells treated or not with BSO and stimulated with TNF $\alpha$ was performed by using their inhibitor TAPI-1 [Liu et al., 2014]. Moreover, at the same time, both sICAM-1 release in culture medium and intracellular ICAM-1 levels in cell lysates were measured by ELISA kit. Data reported in Figure 4A show that BSO, TNF $\alpha$, and $\mathrm{BSO}+\mathrm{TNF} \alpha$, at both concentrations, increased intracellular ICAM-1 in agreement with the expression trend previously detected by Western blot analysis (Fig. 2A). Under these conditions TAPI-1 significantly up-regulated intracellular ICAM-1 levels (Fig. 4A) and down-regulated sICAM-1 release (Fig. 4B), as compared to the respective untreated cells. In particular, TAPI-1 treatment restored s-ICAM-1 release to control values in TNF $\alpha 1$ stimulated 18Co cells treated or not with BSO, but not in all cells stimulated with TNF $\alpha 10$ (Fig. 4B). Treatment of the cells with DPI, inhibitor of NADPH oxidase major producer of ROS in many cells [Panday et al., 2015], inhibited markedly both intracellular ICAM-1 and sICAM-1 release in all conditions used, as compared to the respective untreated 18Co cells (Fig. 4A, B), in accordance with the results obtained with NAC (Figs. 2B and 3). In fact, Figure 5 shows that DPI reduced also ROS production in agreement with the behavior of ROS detected in the same conditions with NAC treatment (Fig. 1).

\section{EFFECT OF BSO, NAC, DPI, AND TNF $\alpha$ ON TACE EXPRESSION AND ACTIVATION IN 18Co CELLS}

TACE expression and activation, detected by Western blot assay, were measured by densitometric analysis of pro-TACE at $120 \mathrm{kDa}$ and mature (active) TACE at $80 \mathrm{kDa}$ bands, respectively. These enhanced both in BSO treated and in TNF $\alpha$ stimulated cells, as compared to the respective controls (Fig. 6A). Both expression and activation of TACE significantly increased in TNF $\alpha 1+$ BSO cells, when compared with 18 Co BSO treated or TNF $\alpha 1$ stimulated cells, reaching the values measured in all cells stimulated with TNF $\alpha 10$. Thr735 phosphorylation of TACE cytoplasmic tail is very important for TACE mobilization to plasma membrane and activation [Scheller et al., 2011]. The use of a specific antibody, which detects endogenous levels of TACE phosphorylation only when phosphorylated at Thr735, shows that the trend of this phosphorylation, relative to $80 \mathrm{kDa}$ band, was similar to that of TACE activation in all conditions used (Fig. 6A). However, the proportion of TACE phosphorylated, calculated by ratio between bands of TACE P-Thr735 and those of pro-TACE $(120 \mathrm{kDa})$, was similar in all conditions (Fig. 6B). Moreover, Figure 6B shows also that mature TACE was all phosphorylated, as indicated by ratio between bands of TACE P-Thr735 and those of TACE at $80 \mathrm{kDa}$. Treatment with NAC and DPI restored TACE expression, activation and phosphorylation to values of control in all conditions (Fig. 7A, B).

\section{DISCUSSION}

In the present study, we examined the role of intracellular oxidative stress on ICAM-1 expression and sICAM-1 release in 18Co cells stimulated or not with TNF $\alpha$. In particular, we demonstrated, for the first time, an increase of ICAM-1 expression and sICAM-1 release in condition of oxidative stress in 18Co cells. The involvement of redox regulated MMPs in the up-regulation of sICAM-1 release has been also demonstrated. Moreover, this study shows ROS dependent increase of TACE activation and expression suggesting its possible 


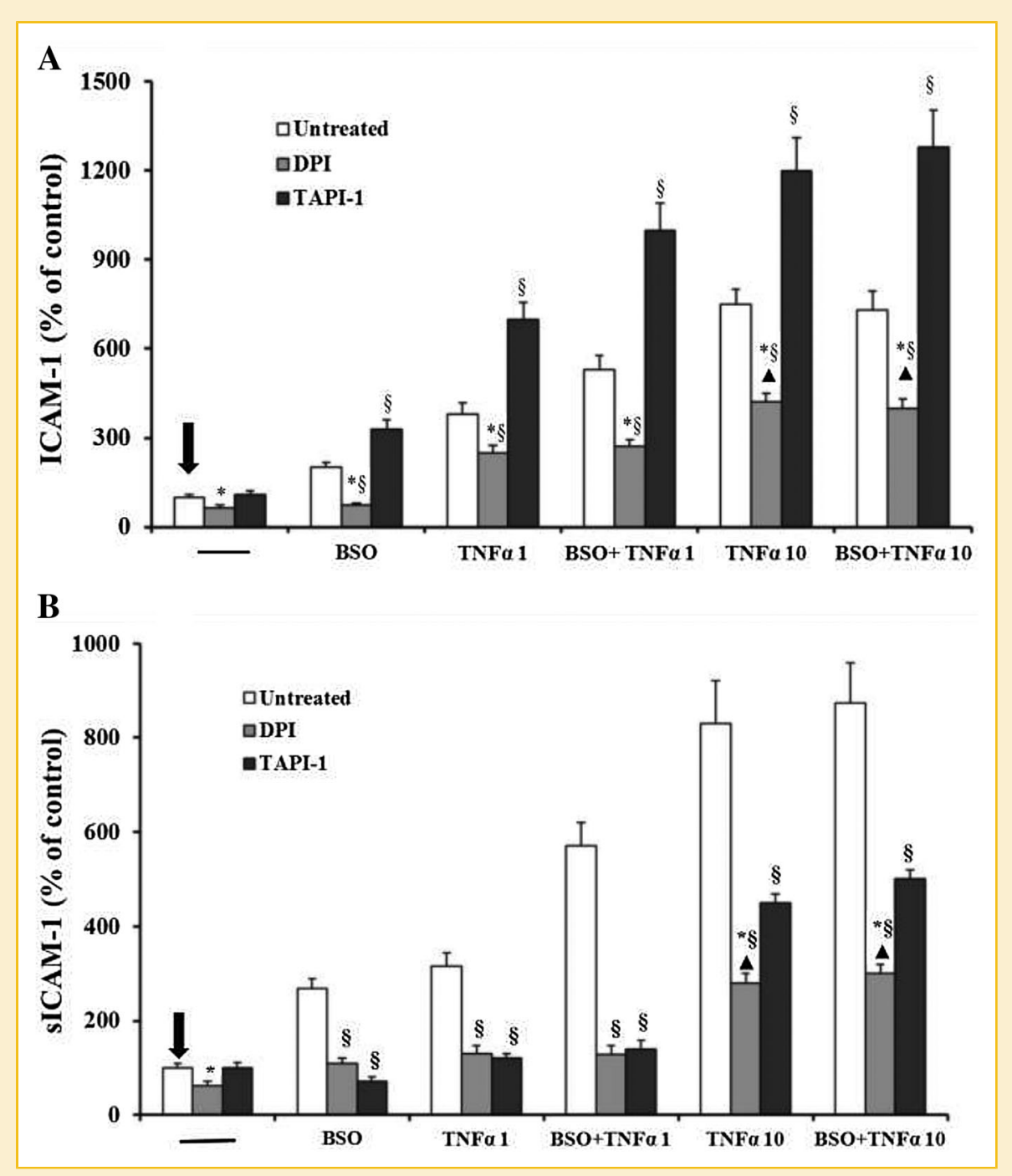

Fig. 4. Effect of TAPI-1 and DPI on intracellular ICAM-1 levels and sICAM-1 levels in 18Co cells treated or not with BSO and stimulated with TNF $\alpha$. $10 \mu M$ TAPI-1 or $10 \mu M$ DPI were added to starved cells treated or not with $25 \mu \mathrm{M}$ BSO and stimulated or not for $24 \mathrm{~h}$ with $1 \mathrm{ng} / \mathrm{ml} \mathrm{TNF} \boldsymbol{\alpha}$ (TNF $\alpha$ ) or $10 \mathrm{ng} / \mathrm{ml} \mathrm{TNF} \boldsymbol{\alpha}$ (TNF $\alpha 10$ ), as reported in Materials and Methods. Intracellular ICAM-1 levels (A) and sICAM-1 (B) assays were performed by ELISA kit in cell lysates and in culture medium, respectively. The values, expressed as percent of untreated and unstimulated cells (control, $100 \%$, indicated with the arrow), are the mean $\pm \mathrm{SEM}$ of six experiments repeated in triplicate. ${ }^{*} P \leq 0.05$ compared to the control cells; ${ }^{\S} P \leq 0.05$ compared to the respective untreated cells; ${ }^{\Delta} P \leq 0.05$ compared to the respective TNF $\alpha 1$ stimulated cells.

role in the up-regulation of sICAM-1 release. In particular, BSO treatment or TNF $\alpha$ stimulation of 18Co cells induce a rise of ROS production related to an increase of ICAM-1 expression and sICAM-1 release. In fact, NAC and DPI treatments reduce or restore ROS production to control and down-regulate ICAM-1 expression and release. TNF $\alpha$ causes oxidative stress [Woo et al., 2000; Lee et al., 2013] and induces ROS production in a concentration-dependent manner. However, in BSO treated cells, only the physiological concentration of TNF $\alpha(1 \mathrm{ng} / \mathrm{ml})$ is able to increase ROS production reaching the value obtained in cells stimulated with $10 \mathrm{ng} / \mathrm{ml} \mathrm{TNF} \alpha$. This suggests that TNF $\alpha$ at physiological concentrations, in the presence of intracellular oxidative stress, increases this inducing tissue damage as it occurs in pathological concentrations. This is particularly important in pathologies, as IBD, in which a condition of oxidative stress is present [Iantomasi et al., 1994; Buffinton and Doe, 1995; O'Connor et al., 2010; Catarzi et al., 2011a]. It is to note that ROS production is similar in BSO treated or TNF $\alpha 1$ stimulated cells whereas ICAM-1 expression is different. In fact, ICAM-1 expression is higher in TNF $\alpha 1$ stimulated cells than in cells treated with BSO. NAC treatment down-regulates ICAM-1 expression only in control and in BSO treated 18Co cells in according to ROS levels. NAC lowers the expression of ICAM-1 levels, but is not able to restore them to the control values in cells stimulated with both concentrations of TNF $\alpha$, differently to that occurs for ROS production. These results indicate that the up-regulation of ICAM-1 expression in TNF $\alpha$ stimulated 18 Co cells, is partially dependent on ROS production and is related to TNF $\alpha$ concentrations through a ROS-independent mechanism. Oxidative stress induces ICAM-1 expression [Roebuck et al., 


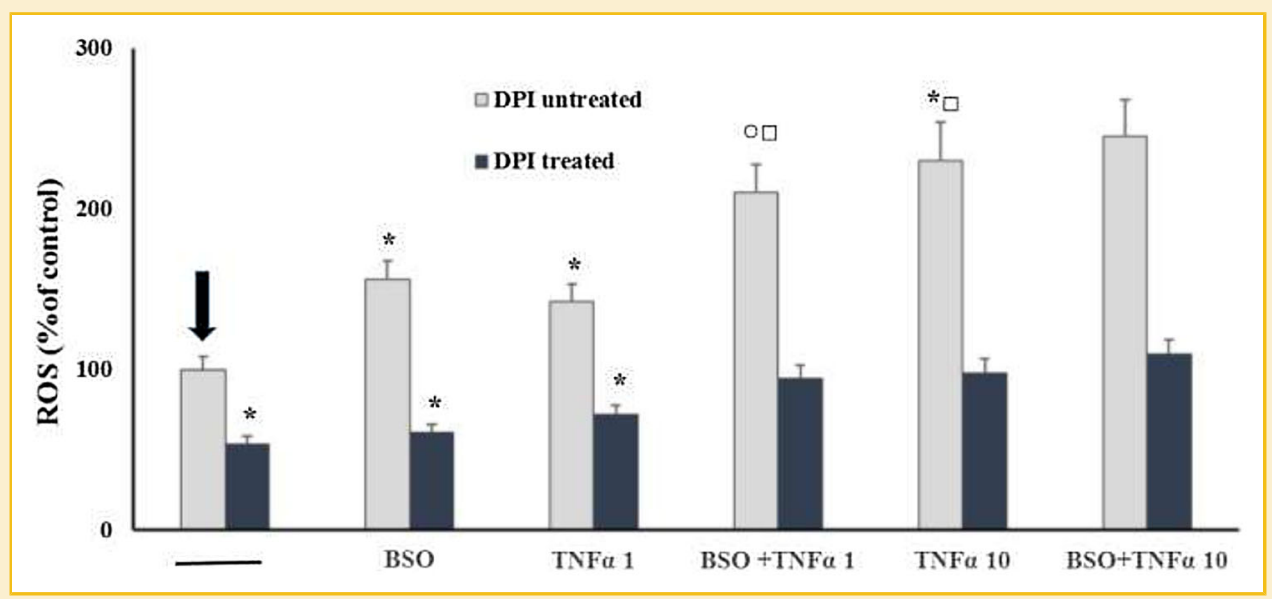

Fig. 5. Effect of DPI on intracellular ROS production in 18 Co cells treated with BSO and stimulated with TNF $\alpha$. Starved $18 \mathrm{Co}$ cells, treated or not with $25 \mu \mathrm{M} B S O$ in the presence of $10 \mu \mathrm{M}$ DPl as reported in Materials and Methods, were stimulated or not for $24 \mathrm{~h}$ with $1 \mathrm{ng} / \mathrm{ml} \mathrm{TNF} \boldsymbol{\alpha}$ (TNF $\boldsymbol{\alpha} 1)$ or $10 \mathrm{ng} / \mathrm{ml}$ TNF $\boldsymbol{\alpha}$ (TNF $\boldsymbol{\alpha} 10) .0 .003 \%$ DMSO (vehicle for DPI) was added to DPI untreated cells. The intracellular ROS production was detected by measuring the fluorescence intensity of the intracellular oxidation-sensitive probe $\mathrm{H}_{2}$ DCFDA. The values, normalized on total protein content and expressed as percent of untreated and unstimulated cells (control, $100 \%$, indicated with the arrow), are the mean \pm SEM of six experiments repeated in triplicate. ${ }^{*} \boldsymbol{P} \leq 0.05$ compared to the control cells; $\square \boldsymbol{P} \leq 0.005$ compared to DPI untreated and TNF $\alpha 1$ stimulated cells; ${ }^{\circ} \boldsymbol{P} \leq 0.001$ compared to DPI untreated and BSO treated cells.

1995] whose redox regulation occurs at different levels being cell type- and stimulus-dependent [Roebuck and Finnegan, 1999]. In lung epithelial cells, TNF $\alpha$-induced ICAM-1 increase is due to the activation of redox regulated signaling pathways, and in fact, it is inhibited by pre-treatment with NADPH-oxidase inhibitor or antioxidants [Kim et al., 2008; Lee et al., 2013; Yen et al., 2013]. However, in endothelial cells TNF $\alpha$ stimulation of ICAM- 1 is different from that induced by exogenous $\mathrm{H}_{2} \mathrm{O}_{2}$ [Roebuck and Finnegan, 1999], and the down-regulation of $\mathrm{TNF} \alpha$-induced myogenesis occurs in murine skeletal muscle cells through redoxdependent and -independent pathways [Langen et al., 2002]. The treatment of $18 \mathrm{Co}$ cells with DPI demonstrates the possible involvement of NADPH oxidase in the increase of ICAM-1 levels; in fact this enzyme represents the principal source of ROS induced by TNF $\alpha$ [Li et al., 2005]. However, DPI, similarly to NAC, reduces ROS levels, but does not remove totally the effect of TNF $\alpha$ on ICAM- 1 expression. This confirms also the involvement of a redoxindependent regulation in the increase of TNF $\alpha$-induced ICAM-1 expression in 18Co cells.

A closer relationship is demonstrated between sICAM-1 release and the oxidative stress. This is especially evident in 18Co cells treated with BSO or stimulated with TNF $\alpha$, also in the presence of NAC and DPI treatments. On the contrary, sICAM- 1 release in TNF $\alpha$ 10 stimulated cells is only in part related to ROS production, given that NAC and DPI do not restore sICAM-1 levels to those of control, differently to that occurs for ROS levels. Therefore, we suggest that TNF $\alpha$ at high concentrations up-regulates sICAM- 1 release also by activating other redox-independent mechanisms responsible for proteolytic cleavage of cell surface ICAM-1. sICAM-1 release was significantly inhibited by TAPI-1, indicating that redox regulated MMPs are involved in the cleavage of transmembrane ICAM-1 induced by oxidative stress in 18Co cells. Alterations of the cellular redox state may regulate both activation and expression of TACE, a protease that cleaves membrane-bound proteins [Scheller et al., 2011]. However, in literature no data are reported on the expression, activation and regulation of this enzyme in ISEMFs in the presence or not of changes in intracellular oxidative state. For the first time, in 18 Co cells an up-regulation of the expression and activation of TACE, related to intracellular oxidative stress, has been demonstrated. In fact, TACE expression and activation correlate with ROS levels in cells treated with BSO and/or stimulated with TNF $\alpha$. Moreover, NAC and DPI treatments restore them to control values in all conditions. Given this and considering that some authors indicate TAPI-1 as specific inhibitor of TACE [Liu et al., 2014], a possible role of TACE in the cleavage of ICAM-1 in the presence of oxidative stress cannot be excluded. The simultaneous enhancement of endogenous ICAM-1 detected in TAPI- 1 treated cells can be due to the inhibition of ICAM-1 shedding. Moreover, it is also possible that, in TNF $\alpha$ treated cells, TAPI-1 blocks TACE-mediated generation of antagonistic soluble TNF $\alpha$ receptors [Scheller et al., 2011]. This can increase ICAM-1 expression trough an enhanced cell stimulation by TNF $\alpha$. Exogenous $\mathrm{H}_{2} \mathrm{O}_{2}$ activates TACE, involving the cysteinyl sulphydryl groups in the extracellular domain [Wang et al., 2009], and increases its cell surface expression via p38-mediated TACE phosphorylation [Brill et al., 2009]. In fact, the activation of this MAPK leads to specific phosphorylation of Thr735 involved in the TACE translocation to membrane and activation. In our conditions, the trend of Thr735 phosphorylation relative to $80 \mathrm{kDa}$ band agrees with TACE activation and it is related to ROS levels. The increased phosphorylation of TACE correlates with the up-regulation of its expression. In fact, the absolute values of TACE phosphorylation change, whereas the proportion of phosphorylated TACE is similar in all conditions. We suggest the involvement of p38 MAPK on TACE phophorylation, considering that a redox-regulated activation of this MAPK occurs in 18 Co cells stimulated or not with TNF $\alpha$ and in ISEMFs isolated from intestine of CD patients [Catarzi et al., 2011a]. Therefore, the redox 


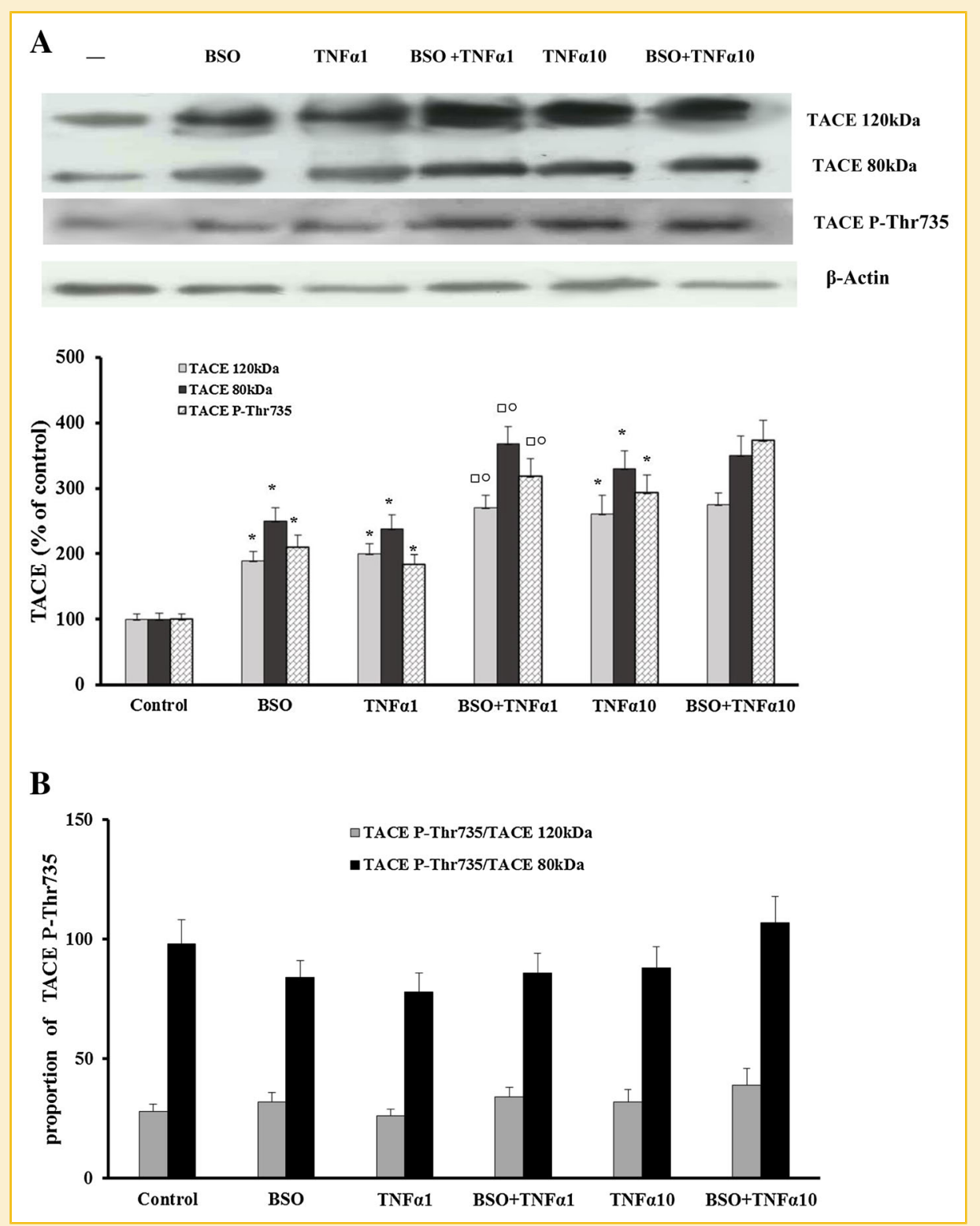

Fig. 6. TACE expression and activation in $18 \mathrm{Co}$ cells treated or not with BSO and stimulated with TNF $\alpha$. Starved cells, treated or not with $25 \mu M$ BSO as reported in Materials and Methods, were stimulated or not for $24 \mathrm{~h}$ with $1 \mathrm{ng} / \mathrm{ml}$ TNF $\boldsymbol{\alpha}$ (TNF $\alpha 1)$ or $10 \mathrm{ng} / \mathrm{ml} \mathrm{TNF} \boldsymbol{\alpha}$ (TNF $\alpha 10)$. Western blot analysis of cell lysate with anti-TACE or anti-ADAM17phosphoThr735 or anti $\boldsymbol{\beta}$-actin was performed for the detection of TACE expression and activation. The TACE P-Thr735 was detected on $80 \mathrm{kDa}$ band. A: Blots are representative of four experiments and normalized values with actin band obtained by densitometric analysis of four experiments are reported in the bottom. The values are the mean percentage \pm SEM relative to those obtained in the untreated and unstimulated cells (control, 100\%). B: The proportion of TACE phosphorylated was calculated both by ratio between bands of TACE P-Thr735 and those of pro-TACE $(120 \mathrm{kDa})$ and by ratio between bands of TACE P-Thr735 and those of mature TACE ( $80 \mathrm{kDa})$. $P \leq 0.005$ compared to the control cells. $\square P \leq 0.05$ compared to the respective TNF $\alpha 1$ stimulated cells ${ }^{\circ} P \leq 0.05$ compared to the respective BSO treated cells.

regulation of TACE expression and activation, detected in intestinal myofibroblasts by us, may be involved in the pro-inflammatory activity of TNF $\alpha$ in inflamed gut. In fact, myofibroblasts produce TNF $\alpha$ in intestinal inflammatory state and, in CD patients, they show high expression of transmembrane TNF $\alpha$ [Di Sabatino et al., 2007]. Moreover, TACE is required in cell surface proteolytic processing of $\mathrm{TNF} \alpha$ that after cleavage assumes its inflammatory properties [Scheller et al., 2011].
ICAM-1 is involved in the recruitment of immune cells at inflammatory sites, and the infiltration and migration of leukocytes into inflamed intestinal mucosa and submucosal layers are crucial for the pathogenesis of IBD [Binion et al., 2009]. ISEMFs produce molecules that contribute to this migration [Pinchuk et al., 2010], therefore the up-regulation of ICAM-1 induced by oxidative stress and TNF $\alpha$ stimulation in ISEMFs can be involved in the excessive migration of leukocytes to the site of local gastrointestinal mucosal 


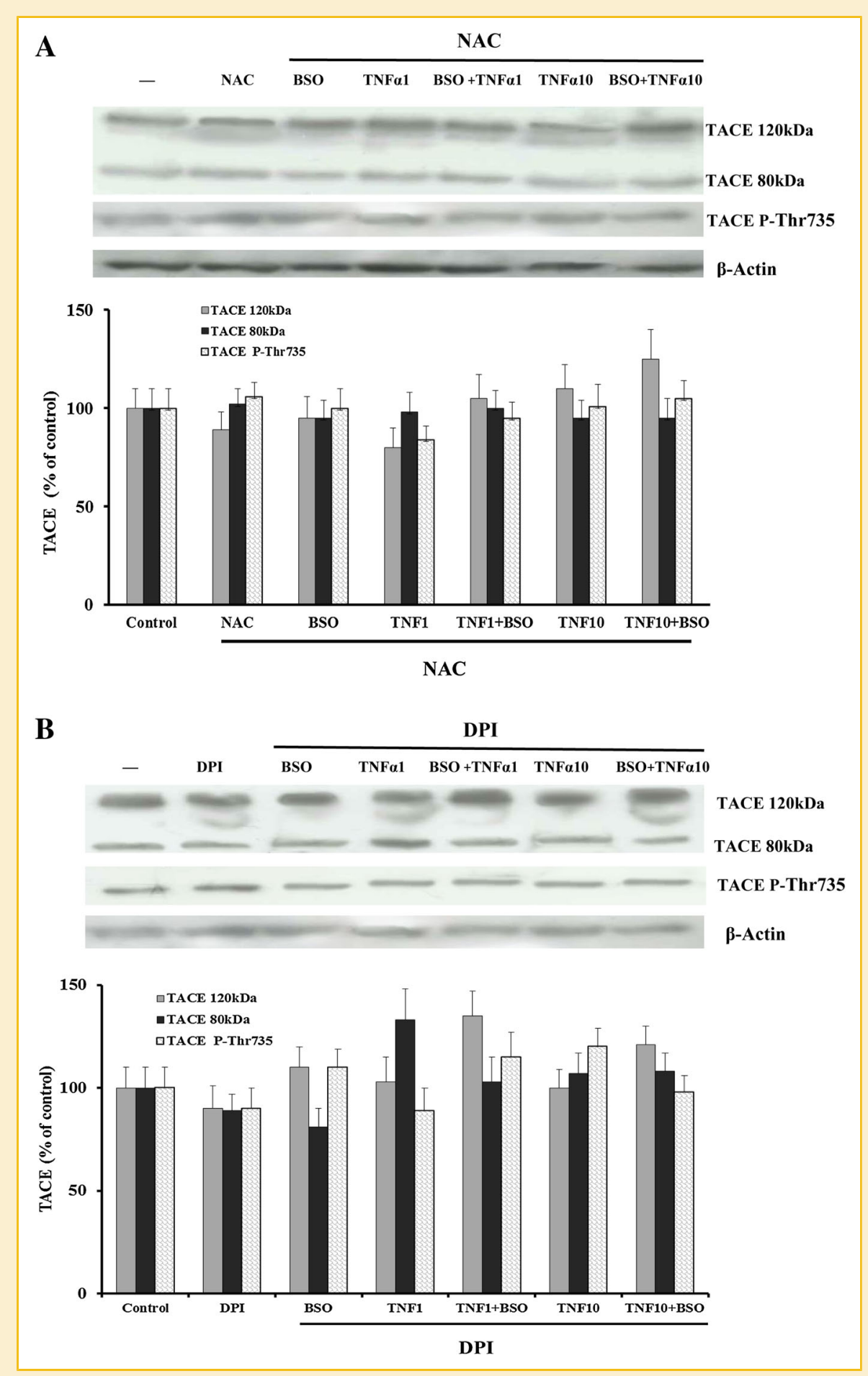

Fig. 7. Effect of NAC or DPI on TACE expression and activation in 18 Co cells treated or not with BSO and stimulated with TNF $\alpha .20 \mathrm{mM}$ NAC or $10 \mu \mathrm{M}$ DPI were added to starved cells treated or not with $25 \mu \mathrm{M}$ BSO and stimulated or not for $24 \mathrm{~h}$ with $1 \mathrm{ng} / \mathrm{ml}$ TNF $\boldsymbol{\alpha}$ (TNF $\boldsymbol{\alpha} 1$ ) or $10 \mathrm{ng} / \mathrm{ml} \mathrm{TNF} \boldsymbol{\alpha}$ (TNF $\boldsymbol{\alpha} 10$ ), as reported in Materials and Methods. $0.003 \%$ DMSO (vehicle for DPI) was added to DPI untreated cells. Western blot analysis of cell lysate with anti-TACE or anti-ADAM17-phosphoThr735 or anti $\boldsymbol{\beta}$-actin was performed for the detection of TACE expression and activation. The TACE P-Thr735 was detected on $80 \mathrm{kDa}$ band. Blots are representative of four experiments and normalized values with actin band obtained by densitometric analysis of four experiments are reported in the bottom. The values are the mean percentage \pm SEM relative to those obtained in the untreated and unstimulated cells (control, 100\%). 
inflammation. Then, we speculate that this could be in part responsible of the excessive recruitment of leukocytes in $\mathrm{CD}$ patient intestine. In fact, an oxidative state condition is present also in ISEMFs [Iantomasi et al., 1994; Catarzi et al., 2011a] as well as an increase of ICAM-1 and sICAM-1 in CD intestinal tissue [Ghosh and Panaccione, 2010]. The increase of sICAM-1 levels in conditions of oxidative stress and/or TNF $\alpha$ stimulation suggests also that ISEMFs can contribute in the enhancement of sICAM-1 levels in serum of IBD patients. In fact, it has been demonstrated that the increase of sICAM-1 in the blood of these patients is related to the levels present in intestinal mucosa and derives from activated cells within gut mucosa and not from circulating leukocytes [Nielsen et al., 1994; Song et al., 2009]. NAC, down-regulating ICAM-1 expression and sICAM-1 release in ISEMFs, can reduce the excessive recruitment of immune cells in intestinal mucosa, the activation of inflammatory cascade and angiogenesis, preventing the onset and the progression of chronic inflammatory diseases [Lawson and Wolf, 2009; AngelMorales et al., 2012]. Moreover, the reduction of ICAM-1expression and of its soluble form by antioxidants treatment could interfere with the tumor differentiation and the metastasis development. In fact, intestinal myofibroblasts regulate the migration, differentiation and growth of normal and carcinoma cells [Pinchuk et al., 2010], and the chronic inflammation can favor the development of colon cancer [Grivennikov, 2013]. Since our results show that in TNF $\alpha$ stimulated 18 Co cells NAC treatment reduces in part ICAM-1 expression and sICAM-1 release, we speculate that the synergistic effect between the antioxidants and anti- TNF $\alpha$ drugs could be therapeutically useful.

\section{CONCLUSIONS}

All together, our data demonstrate, for the first time in 18Co cells, an up-regulation of ICAM-1 expression and sICAM-1 release induced by oxidative stress and $\mathrm{TNF} \alpha$ stimulation, showing a redox regulation of these events. However, also redox-independent mechanisms in ICAM-1 expression and release are probable in TNF $\alpha$ stimulated cells. It was shown that cleavage of ICAM-1 on cell surface is mediated by redox regulated MMPs. Moreover, we suggest the possible involvement of TACE, whose expression and activation in 18Co cells have been related to ROS levels. An involvement of NADPH oxidase in the redox regulation of ICAM-1 and TACE has been demonstrated.

\section{ACKNOWLEDGMENT}

This study was supported by a donation from Fondazione Cassa di Risparmio di Firenze.

\section{REFERENCES}

Alexiou D, Karayiannakis AJ, Syrigos KN, Zbar A, Kremmyda A, Bramis I, Tsigris C. 2001. Serum levels of E-selectin, ICAM-1 and VCAM-1 in colorectal cancer patients: Correlations with clinicopathological features, patient survival and tumour surgery. Eur J Cancer 37:2392-2397.

Angel-Morales G, Noratto G, Mertens-Talcott S. 2012. Red wine polyphenolics reduce the expression of inflammation markers in human colon- derived CCD-18Co myofibroblast cells: Potential role of microRNA-126. Food Funct 3:745-752.

Arteta B, Lasuen N, Lopategi A, Sveinbjörnsson B, Smedsrùd B, VidalVanaclocha F. 2010. Colon carcinoma cell interaction with liver sinusoidal endothelium inhibits organ-specific antitumor immunity through interleukin-1-induced mannose receptor in mice. Hepatology 51:2172-2182.

Biasi F, Leonarduzzi G, Oteiza PI, Poli G. 2013. Inflammatory bowel disease: Mechanisms, redox considerations, and therapeutic targets. Antioxid Redox Signal 19:1711-1747.

Binion DG, Heidemann J, Li MS, Nelson VM, Otterson MF, Rafiee P. 2009. Vascular cell adhesion molecule-1 expression in human intestinal microvascular endothelial cells is regulated by PI 3-kinase/Akt/MAPK/NF-kappaB: Inhibitory role of curcumin. Am J Physiol Gastrointest Liver Physiol 297: G259-G268.

Brill A, Chauhan AK, Canault M, Walsh MT, Bergmeier W, Wagner DD. 2009. Oxidative stress activates ADAM17/TACE and induces its target receptor shedding in platelets in a p38-dependent fashion. Cardiovasc Res 84:137-144.

Buffinton GD, Doe WF. 1995. Depleted mucosal antioxidant defences in inflammatory bowel disease. Free Radic Biol Med 19:911-918.

Catarzi S, Biagioni C, Giannoni E, Favilli F, Marcucci T, Iantomasi T, Vincenzini MT. 2005. Redox regulation of platelet-derived-growth-factorreceptor: Role of NADPH-oxidase and c-Src tyrosine kinase. Biochim Biophys Acta 1745:166-175.

Catarzi S, Favilli F, Romagnoli C, Marcucci T, Picariello L, Tonelli F, Vincenzini MT, Iantomasi T. 2011a. Oxidative state and IL-6 production in intestinal myofibroblasts of Crohn's disease patients. Inflamm Bowel Dis 17:1674-1684.

Catarzi S, Romagnoli C, Marcucci G, Favilli F, Iantomasi T, Vincenzini MT. 2011b. Redox regulation of ERK1/2 activation induced by sphingosine 1-phosphate in fibroblasts: Involvement of NADPH oxidase and plateletderived growth factor receptor. Biochim Biophys Acta 1810:446-456.

Champagne B, Tremblay P, Cantin A, St Pierre Y. 1998. Proteolytic cleavage of ICAM-1 by human neutrophil elastase. J Immunol 161:6398-6405.

Chatterjee S. 1998. Sphingolipids in atherosclerosis and vascular biology. Arterioscler Thromb Vasc Biol 18:1523-1533.

Chidlow JH, Jr, Langston W, Greer JJ, Ostanin D, Abdelbaqi M, Houghton J, Senthilkumar A, Shukla D, Mazar AP, Grisham MB, Kevil CG. 2006. Differential angiogenic regulation of experimental colitis. Am J Pathol 169:2014-2030.

Corredor J, Yan F, Shen CC, Tong W, John SK, Wilson G, Whitehead R, Polk DB. 2003. Tumor necrosis factor regulates intestinal epithelial cell migration by receptor-dependent mechanisms. Am J Physiol Cell Physiol 284: C953-C961.

Di Sabatino A, Pender SL, Jackson CL, Prothero JD, Gordon JN, Picariello L, Rovedatti L, Docena G, Monteleone G, Rampton DS, Tonelli F, Corazza GR, MacDonald TT. 2007. Functional modulation of Crohn's disease myofibroblasts by anti-tumor necrosis factor antibodies. Gastroenterology 133: 137-149.

Feagins LA, Souza RF, Spechler SJ. 2009. Carcinogenesis in IBD: Potential targets for the prevention of colorectal cancer. Nat Rev Gastroenterol Hepatol 6:297-305.

Ghosh S, Panaccione R. 2010. Anti-adhesion molecule therapy for inflammatory bowel disease. Therap Adv Gastroenterol 3:239-258.

Grivennikov SI. 2013. Inflammation and colorectal cancer: Colitis-associated neoplasia. Semin Immunopathol 35:229-244.

Hua S. 2013. Targeting sites of inflammation: Intercellular adhesion molecule- 1 as a target for novel inflammatory therapies. Front Pharmacol 4:127-132.

Iantomasi T, Marraccini P, Favilli F, Vincenzini MT, Ferretti P, Tonelli F. 1994. Glutathione metabolism in Crohn's disease. Biochem Med Metab Biol 53:87-91. 
Kim H, Hwang JS, Woo CH, Kim EY, Kim TH, Cho KJ, Kim JH, Seo JM, Lee SS. 2008. TNF-alpha-induced up-regulation of intercellular adhesion molecule-1 is regulated by a Rac-ROS-dependent cascade in human airway epithelial cells. Exp Mol Med 40:167-175.

Ksiazek K, Mikuła-Pietrasik J, Catar R, Dworacki G, Winckiewicz M, Frydrychowicz M, Dragun D, Staniszewski R, Jörres A, Witowski J. 2010. Oxidative stress-dependent increase in ICAM-1 expression promotes adhesion of colorectal and pancreatic cancers to the senescent peritoneal mesothelium. Int J Cancer 127:293-303.

Langen RC, Schols AM, Kelders MC, Van Der Velden JL, Wouters EF, JanssenHeininger YM. 2002. Tumor necrosis factor-alpha inhibits myogenesis through redox-dependent and -independent pathways. Am J Physiol Cell Physiol 283:C714-C721.

Lawson C, Wolf S. 2009. ICAM-1 signaling in endothelial cells. Pharmacol Rep 61:22-32.

Lee IT, Lin CC, Lee CY, Hsieh PW, Yang CM. 2013. Protective effects of (-)-epigallocatechin-3-gallate against TNF- $\alpha$-induced lung inflammation via ROS-dependent ICAM-1 inhibition. J Nutr Biochem 24:124-136.

Li JM, Fan LM, Christie MR, Shah AM. 2005. Acute tumor necrosis factor alpha signaling via NADPH oxidase in microvascular endothelial cells: Role of p47phox phosphorylation and binding to TR AF4. Mol Cell Biol 25:2320-2330.

Liu FL, Wu CC, Chang DM. 2014. TACE-dependent amphiregulin release is induced by IL- $1 \beta$ and promotes cell invasion in fibroblast-like synoviocytes in rheumatoid arthritis. Rheumatology (Oxford) 53:260-269.

Maeda K, Kang SM, Sawada T, Nishiguchi Y, Yashiro M, Ogawa Y, Ohira M, Ishikawa T, Hirakawa YS, Chung K. 2002. Expression of intercellular adhesion molecule-1 and prognosis in colorectal cancer. Oncol Rep 9:511-514.

McCabe SM, Riddle L, Nakamura GR, Prashad H, Mehta A, Berman PW, Jardieu P. 1993. SICAM-1 enhances cytokine production stimulated by alloantigen. Cell Immunol 150:364-375.

Metselaar JM, Storm G. 2005. Liposomes in the treatment of inflammatory disorders. Expert Opin Drug Deliv 2:465-476.

Nakata B, Hori T, Sunami T, Ogawa Y, Yashiro M, Maeda K, Sawada T, Kato Y, Ishikawa T, Hirakawa K. 2000. Clinical significance of serum soluble intercellular adhesion molecule 1 in gastric cancer. Clin Cancer Res 6:1175-1179.

Nielsen OH, Langholz E, Hendel J, Brynskov J. 1994. Circulating soluble intercellular adhesion molecule-1 (sICAM-1) in active inflammatory bowel disease. Dig Dis Sci 39:1918-1923.

0'Connor PM, Lapointe TK, Beck PL, Buret AG. 2010. Mechanisms by which inflammation may increase intestinal cancer risk in inflammatory bowel disease. Inflamm Bowel Dis 16:1411-1420.

0'Hanlon DM, Fitzsimons H, Lynch J, Tormey S, Malone C, Given HF. 2002. Soluble adhesion molecules (E-selectin, ICAM-1 and VCAM-1) in breast carcinoma. Eur J Cancer 38:2252-2257.

Otto VI, Heinzel-Pleines UE, Gloor SM, Trentz 0, Kossmann T, MorgantiKossmann MC. 2000. SICAM-1 and TNF-alpha induce MIP-2 with distinct kinetics in astrocytes and brain microvascular endothelial cells. J Neurosci Res 60:733-742.

Otto VI, Gloor SM, Frentzel S, Gilli U, Ammann E, Hein AE, Folkers G, Trentz 0, Kossmann T, Morganti-Kossmann MC. 2002. The production of macrophage inflammatory protein-2 induced by soluble intercellular adhesion molecule- 1 in mouse astrocytes is mediated by src tyrosine kinases and p42/ 44 mitogen-activated protein kinase. J Neurochem 80:824-834.

Panday A, Sahoo MK, Osorio D, Batra S. 2015. NADPH oxidases: An overview from structure to innate immunity-associated pathologies. Cell Mol Immunol 12:5-23.

Pang G, Couch L, Batey R, Clancy R, Cripps A. 1994. GM-CSF, IL-1 alpha, IL-1 beta, IL-6, IL-8, IL-10, ICAM-1 and VCAM-1 gene expression and cytokine production in human duodenal fibroblasts stimulated with lipopolysaccharide, IL-1 alpha and TNF-alpha. Clin Exp Immunol 96:437-443.

Perabo F, Sharma S, Gierer R, Wirger A, Fimmers R, Steiner G, Adam M, Schultze-Seemann W. 2001. Circulating intercellular adhesion molecule-1 (ICAM-1), vascular cell adhesion molecule-1 (VCAM-1) and E-selectin in urological malignancies. Indian J Cancer 38:1-7.

Pina-Canseco Mdel S, Páez-Arenas A, Massó F, Pérez-Campos E, MartínezCruz R, Hernández-Cruz P, Majluf-Cruz A, Martínez-Cruz M, Pérez-Campos Mayoral L, Pérez-Santiago AD, Zenteno E. 2012. Protein C activation peptide inhibits the expression of ICAM-1, VCAM-1, and interleukin-8 induced by TNF- $\alpha$ in human dermal microvascular endothelial cells. Folia Histochem Cytobiol 50:407-143.

Pinchuk IV, Mifflin RC, Saada JI, Powell DW. 2010. Intestinal mesenchymal cells. Curr Gastroenterol Rep 12:310-318.

Roebuck KA, Rahman A, Lakshminarayanan V, Janakidevi K, Malik AB. 1995. $\mathrm{H}_{2} \mathrm{O}_{2}$ and tumor necrosis factor-alpha activate intercellular adhesion molecule 1 (ICAM-1) gene transcription through distinct cis-regulatory elements within the ICAM-1 promoter. J Biol Chem 270:18966-18974.

Roebuck KA, Finnegan A. 1999. Regulation of intercellular adhesion molecule-1 (CD54) gene expression. J Leukoc Biol 66:876-888.

Roland CL, Harken AH, Sarr MG, Barnett CC, Jr. 2007. ICAM-1 expression determines malignant potential of cancer. Surgery 141:705-707.

Roland CL, Dineen SP, Toombs JE, Carbon JG, Smith CW, Brekken RA, Barnett CC, Jr. 2010. Tumor-derived intercellular adhesion molecule-1 mediates tumor-associated leukocyte infiltration in orthotopic pancreatic xenografts. Exp Biol Med (Maywood) 235:263-270.

Scheller J, Chalaris A, Garbers C, Rose-John S. 2011. ADAM17: A molecular switch to control inflammation and tissue regeneration. Trends Immunol 32:380-387.

Schmal H, Czermak BJ, Lentsch AB, Bless NM, Beck-Schimmer B, Friedl HP, Ward PA. 1998. Soluble ICAM-1 activates lung macrophages and enhances lung injury. J Immunol 161:3685-3693.

Smith PK, Krohn RI, Hermanson GT, Mallia AK, Gartner FH, Provenzano MD, Fujimoto EK, Goeke NM, Olson BJ, Klenk DC. 1985. Measurement of protein using bicinchoninic acid. Anal Biochem 150:76-85.

Song WB, Lv YH, Zhang ZS, Li YN, Xiao LP, Yu XP, Wang YY, Ji HL, Ma L. 2009. Soluble intercellular adhesion molecule-1, D-lactate and diamine oxidase in patients with inflammatory bowel disease. World J Gastroenterol 15:3916-3919.

Taglia L, Matusiak D, Matkowskyj KA, Benya RV. 2007. Gastrin-releasing peptide mediates its morphogenic properties in human colon cancer by upregulating intracellular adhesion protein-1 (ICAM-1) via focal adhesion kinase. Am J Physiol Gastrointest Liver Physiol 292:G182-G190.

Tsakadze NL, Sithu SD, Sen U, English WR, Murphy G, D'Souza SE. 2006. Tumor necrosis factor-alpha-converting enzyme (TACE/ADAM-17) mediates the ectodomain cleavage of intercellular adhesion molecule-1 (ICAM-1). J Biol Chem 281:3157-3164.

Vainer B, Nielsen OH, Horn T. 2000. Comparative studies of the colonic in situ expression of intercellular adhesion molecules (ICAM-1, -2, and -3), beta2 integrins (LFA-1, Mac-1, and p150,95), and PECAM-1 in ulcerative colitis and Crohn's disease. Am J Surg Pathol 24:1115-1124.

Valentich JD, Popov V, Saada JI, Powell DW. 1997. Phenotypic characterization of an intestinal subepithelial myofibroblast cell line. Am J Physiol 272:C1513-C1524.

Van Assche G, Rutgeerts P. 2005. Physiological basis for novel drug therapies used to treat the inflammatory bowel diseases. I. Immunology and therapeutic potential of antiadhesion molecule therapy in inflammatory bowel disease. Am J Physiol Gastrointest Liver Physiol 288:G169-G174.

Wang Y, Herrera AH, Li Y, Belani KK, Walcheck B. 2009. Regulation of mature ADAM17 by redox agents for L-selectin shedding. J Immunol 182:24492457. 
Woo CH, Eom YW, Yoo MH, You HJ, Han HJ, Song WK, Yoo YJ, Chun JS, Kim JH. 2000. Tumor necrosis factor-alpha generates reactive oxygen species via a cytosolic phospholipase A2-linked cascade. J Biol Chem 275:32357-32362.

Yen FL, Tsai MH, Yang CM, Liang CJ, Lin CC, Chiang YC, Lee HC, Ko HH, Lee CW. 2013. Curcumin nanoparticles ameliorate ICAM-1 expression in TNF- $\alpha-$ treated lung epithelial cells through p47 (phox) and MAPKs/AP-1 pathways. PLoS ONE 8,DOI: 10.1371/journal.pone.0063845.
Yeung TM, Buskens C, Wang LM, Mortensen NJ, Bodmer WF. 2013. Myofibroblast activation in colorectal cancer lymph node metastases. Br J Cancer 108:2106-2115.

Ying B, Yang T, Song X, Hu X, Fan H, Lu X, Chen L, Cheng D, Wang T, Liu D, Xu D, Wei Y, Wen F. 2009. Quercetin inhibits IL-1 beta-induced ICAM-1 expression in pulmonary epithelial cell line A549 through the MAPK pathways. Mol Biol Rep 36:1825-1832. 